\title{
Twister Proteico: uma ferramenta lúdica envolvendo a síntese de proteínas
}

\section{Twister Protein: a ludic tool involving protein synthesis}

\author{
Aline Weyh ${ }^{1 *}$, Ísis Gabriela Barbosa Carvalho ${ }^{2}$, Analía del Valle Garnero ${ }^{1}$ \\ ${ }^{1}$ Universidade Federal do Pampa - Campus São Gabriel/RS \\ ${ }^{2}$ Universidade Federal de São Carlos - São Carlos/SP \\ *e-mail: alineweyh.aw@gmail.com
}

\begin{abstract}
Resumo
Diversos estudos demonstram que discentes dos mais variados níveis escolares relatam a Genética como um tema abstrato e de difícil compreensão pelos alunos, apresentando múltiplas problemáticas no processo de ensino-aprendizagem e tornando-se necessárias práticas auxiliares. Dentre as ferramentas didáticas, o jogo é uma atividade lúdica muito utilizada atualmente, uma vez que, estimula as várias inteligências e permite maior interação entre aluno e professor. O presente trabalho busca a elaboração e aplicação de um jogo didático inovador e dinâmico, o Twister Proteico, como recurso pedagógico para a disciplina de Genética. A elaboração do jogo foi baseada na utilização de materiais de fácil acesso e baixo custo pelo educando podendo abordar conhecimentos de transcrição, tradução e dobramento proteico. A atividade foi proposta e aplicada em sala de aula tendo como piloto alunos de graduação. A diversão associada ao conhecimento da ciência permitiu não apenas uma melhor memorização do conteúdo abordado, como despertou a curiosidade, reflexão do tema, construção do caráter e espírito de colaboração, além da competitividade através da interação entre a turma. Esta prática mostrou-se uma ferramenta eficaz na fuga da rotina e reparação de falhas do processo de ensino teórico.
\end{abstract}

Palavras-chave: Ensino, Genética, Jogo.

\begin{abstract}
Several studies show that students of various grade levels report the Genetics as an abstract theme and difficult to assimilate by the students, with multiple problems in the teaching-learning process and becoming necessary the development of auxiliary practices. Among the teaching tools, the game is the most currently opted playful activity by stimulating multiple intelligences, allowing greater student-teacher interaction. This work seeks the production of an innovative and dynamic educational game, Twister Protein, as a pedagogical resource for Genetics discipline. The development of the game was based on the use of easily accessible and low cost materials by teachers, allowing the knowledge of transcription, translation and protein folding. The activity was proposed and applied in the classroom with pilot undergraduate students. The fun associated with the knowledge of science not only allowed a better memorization of the content addressed, as aroused the curiosity, theme reflection, character building and collaborative spirits, as well as competitiveness through the interaction between class. This practice proved to be an effective tool in the escape from routine and fault repair of the theoretical process.
\end{abstract}

Keywords: Teaching, Genetics, Game. 


\section{Ficha da atividade desenvolvida}

Título: Twister Proteico: uma ferramenta lúdica envolvendo a síntese de proteínas

Público alvo: Estudantes de nível médio à graduação que abordaram previamente o conteúdo de Genética

Disciplinas relacionadas: Genética e Biologia Celular e Molecular

Objetivos educacionais: Relacionar o conteúdo abordado na aula teórica com uma visão prática, servindo para revisar conceitos e estimular memorização, habilidades pessoais, criatividade, trabalho em equipe, interação entre alunos e entre aluno-professor.

Justificativa de uso: A utilização de abordagens auxiliares de caráter lúdico no ensino para estimular a curiosidade e maior interesse dos alunos na disciplina abordada, revisando conceitos de forma menos rotineira e mais divertida, facilitando a absorção dos mesmos.

Conteúdos trabalhados: Pareamento de bases, transcrição, tradução, estrutura de proteínas, dobramento proteico, ligações entre aminoácidos e funcionalidade proteica. 


\section{Introdução}

O ensino da Genética nos proporciona as bases para um melhor autoconhecimento, o conhecimento alheio e o entendimento do meio em que vivemos. A Genética nos proporciona meios de melhor compreender as relações existentes no cotidiano, todavia, alguns obstáculos ainda precisam ser enfrentados.

As dificuldades encontradas na disciplina de Genética estão relacionadas, muitas vezes, com a falta de interação dos conteúdos, no cotidiano dos alunos. Por exemplo, conceitos de Ácido Desoxirribonucleico (DNA), proteína ou gene, escapam a um acesso sensorial direto dos alunos, ou seja, seu dia a dia. Contudo, a informação que os alunos já possuem acerca destes conceitos ou processos pode interferir no processo de construção de significados, causando distorção do novo conhecimento. Klautau et al. [1] apontam que os estudantes universitários e os de ensino médio consideram a Genética como a disciplina mais difícil da área da biologia.

A compreensão dos conceitos básicos, essencial para o conhecimento de novas tecnologias, pode ser facilitada pela inserção de recursos didáticos no processo ensino aprendizagem [2]. Segundo Krasilchik [3], os jogos didáticos são formas simples de simulação, cuja função é ajudar a memorizar fatos e conceitos. Nessa perspectiva, o jogo não é o fim, mas o eixo que conduz a um conteúdo didático específico, resultando em um empréstimo da ação lúdica para a aquisição de conceitos, mecanismos e novas informações [4].

Segundo os Parâmetros Curriculares Nacionais [5], o estudo das Ciências Naturais deve utilizar diferentes métodos ativos, inclusive jogos, pois um estudo exclusivamente livresco deixa uma enorme lacuna na formação dos estudantes. Macedo et al. [6] apontam a influência da afetividade no desenvolvimento e na aprendizagem, pois dificilmente se adquirem conhecimento sem desejo, interesse e motivação. $O$ uso de jogos no ensino pode atuar como fator motivacional para os alunos.

Os materiais didáticos são considerados ferramentas fundamentais para os processos de ensino e aprendizagem. Os jogos têm sido utilizados com o objetivo de melhorar o rendimento escolar dos alunos, preenchendo lacunas deixadas pelo processo de transmissão do conhecimento, o desenvolvimento do raciocínio do aluno, a socialização, a motivação, a curiosidade e a criatividade [7-9].

Segundo Miranda [10], mediante o jogo didático, vários objetivos podem ser atingidos, relacionados à cognição; afeição; socialização; motivação e criatividade, tais como, desenvolvimento da inteligência e da personalidade, simulação de vida em grupo, envolvimento da ação, do desafio e mobilização da curiosidade. 
Neste sentido, o jogo ganha um espaço como a ferramenta ideal da aprendizagem, na medida em que propõe estímulo ao interesse do aluno, desenvolve níveis diferentes de experiência pessoal e social, ajuda a construir suas novas descobertas, desenvolve e enriquece sua personalidade, e simboliza um instrumento pedagógico que leva o professor à condição de condutor, estimulador e avaliador da aprendizagem [7].

Observando as turmas das disciplinas de Citogenética e Genética Básica da Universidade Federal do Pampa campus São Gabriel, constatamos grande dificuldade do aprendizado de Genética existentes desde os tempos de ensino médio. Estas dificuldades foram percebidas quando os assuntos de transcrição, tradução e dobramento proteico estavam sendo abordados. Grande parte dos alunos não acompanhavam a disciplina e relacionavam a problemática com a falta de práticas e associação com o cotidiano, o que tornava a disciplina estritamente teórica e exaustiva de difícil assimilação.

Assim, a proposta desenvolvida teve por objetivos elaborar, confeccionar, avaliar e divulgar um jogo didático que auxilie na compreensão e aprendizagem do conteúdo de Genética e Bioquímica, tais como: transcrição (síntese da molécula de RNA), tradução (síntese de uma cadeia polipeptídica, que teve por molde uma sequência nucleotídica de uma molécula de mRNA, na qual a sequência de aminoácidos determina uma proteína), dobramento proteico (processo químico onde a estrutura proteica assume sua conformação funcional), ligações entre aminoácidos (ligações químicas que se estabelecem entre aminoácidos), etc. Defendemos a ideia de que os jogos podem merecer um espaço na prática pedagógica dos professores tratando-se de uma estratégia motivadora que agrega aprendizado do conteúdo ao desenvolvimento de aspectos comportamentais saudáveis [9].

\section{Material e métodos}

Twister Proteico é uma atividade desenvolvida como ferramenta de apoio à disciplina de Genética. Este jogo foi elaborado como requisito de avaliação para a disciplina de Citogenética do curso de Bacharel em Biotecnologia da Universidade Federal do Pampa campus São Gabriel. O jogo foi adaptado da versão original Twister ${ }^{\circledR} \mathrm{e}$ foi aplicado em mais de uma turma da disciplina, bem como, em experimentadores voluntários. Na versão original, o objetivo é mover mãos e pés conforme a cor indicada por uma roleta, que é girada por um dos participantes, sem perder o equilíbrio. As cores são dispostas em um tapete e ganha o participante que permanecer mais tempo sem cair. $\mathrm{Na}$ versão adaptada, dentre outras modificações, não é a roleta quem direciona a 
posição, esta, é indicada pelo resultado obtido pelos alunos na etapa anterior, como descrito no tópico 2.2 .

\subsection{Descrição dos componentes do jogo}

Este jogo é composto basicamente por um painel de tecido; fichas representativas de bases nitrogenadas de DNA e Ácido Ribonucleico mensageiro (mRNA), bem como, os 20 aminoácidos; uma tabela com o código genético e papel pardo para compor o "tapete" afixado ao chão.

\subsubsection{Materiais Utilizados}

Espuma Vinílica Acetinada (E.V.A.), várias cores; Plástico adesivo transparente; Caneta hidrográfica preta, vermelha e azul; Papel cartão ou cartolina; Tesoura; Régua; Tecido (Flanela) 1,5 m x 40 cm; Fita velcro; Cola quente; Tinta Guache Branca; Pincel; Papel Pardo 2,00 m x 1,85 m. Fita dupla face.

\subsubsection{Confecção do jogo}

$1^{\circ}$ Passo: Utilizando o papel cartão e as canetas hidrográficas faz-se a tabela com o código genético correspondente a todos os aminoácidos;

$2^{\circ}$ Passo: Utilizando E.V.A. de apenas uma cor (laranja, por exemplo), recorta-se retângulos de aproximadamente $6 \mathrm{~cm} \times 4 \mathrm{~cm}$. Em cada retângulo escreve-se letras correspondentes às bases nitrogenadas do DNA - A, T, C, G com a caneta hidrográfica preta. Cada base terá 15 peças, totalizando 60 peças utilizadas no jogo para elaboração da fita molde de DNA.

Utilizando E.V.A. colorido, recorta-se retângulos de aproximadamente $6 \mathrm{~cm} \times 4 \mathrm{~cm}$. Em cada retângulo escreve-se letras correspondentes às bases nitrogenadas do mRNA A, U, C, G com a caneta hidrográfica preta. Cada base terá 15 peças e uma cor, totalizando 60 peças e 4 cores, utilizadas no jogo para elaboração da fita de mRNA.

Utiliza-se o E.V.A. em várias cores e recorta-se círculos menores que $8 \mathrm{~cm} \mathrm{e}$ círculos maiores que $15 \mathrm{~cm}$ de diâmetro (as cores dos círculos menores serão as mesmas dos círculos grandes). Nestes círculos são escritas as abreviações dos 20 aminoácidos do código genético - Phe (Fenilalanina); Leu (Leucina); Ile (Isoleucina); Met (metionina); Val (Valina); Ser (Serina); Pro (Prolina); Thr (Treonina); Ala (Alanina); Tyr (Tirosina); His (Histidina); Gln (Glutamina); Asn (Aspargina); Lys (Lisina); Asp (Ácido aspártico); Glu (Ácido glutâmico); Cys (Cisteína); Trp (Triptofano); Arg (Arginina); Gly (Glicina). Logo que estiverem secos, os círculos são revestidos com plástico adesivo transparente na face 
escrita. Aconselha-se revestir com plástico adesivo transparente os círculos menores também.

$3^{\circ}$ Passo: Corta-se a fita velcro em tiras de aproximadamente $2 \mathrm{~cm} \times 2 \mathrm{~cm}$ e fixar com a cola quente no verso das bases nitrogenadas e nos círculos menores. Para que as peças possam fixar-se no tecido.

$4^{\circ}$ Passo: Utilizando o tecido na posição horizontal pintar no canto esquerdo superior "DNA" e as extremidades 5' e 3', no lado esquerdo ao meio "mRNA" e as extremidades 5' e 3' e do lado esquerdo inferior "Proteína". (ver figura 1) As palavras necessitam ser proporcionais ao tamanho das bases de E.V.A. A sequência de DNA molde oferecida pelo docente pode ser: 3' TACAATGCTGGGCGAAGTCCTTAGTGACAT ATC 5'. O docente ainda pode oferecer a sequência da fita codificadora, 5' ATGTTACGA CCCGCTTCAGGAATCACTGTATAG 3', e permitir aos alunos identificar a sequência molde de DNA como mais uma etapa de aprendizado.

$5^{\circ}$ Passo: Recortar $10 \mathrm{~cm}$ da fita adesiva dupla face e colar na face não escrita dos círculos maiores. A fita adesiva é utilizada na fixação dos círculos maiores ao papel pardo evitando-se deslizamentos de mãos ou pés. Da mesma forma o papel pardo 2,00 $\mathrm{m} \mathrm{x}$ 1,85 $\mathrm{m}$ deve ser afixado ao chão. A fita adesiva também pode ser utilizada no papel cartão (código genético) se desejar fixá-lo em alguma superfície.

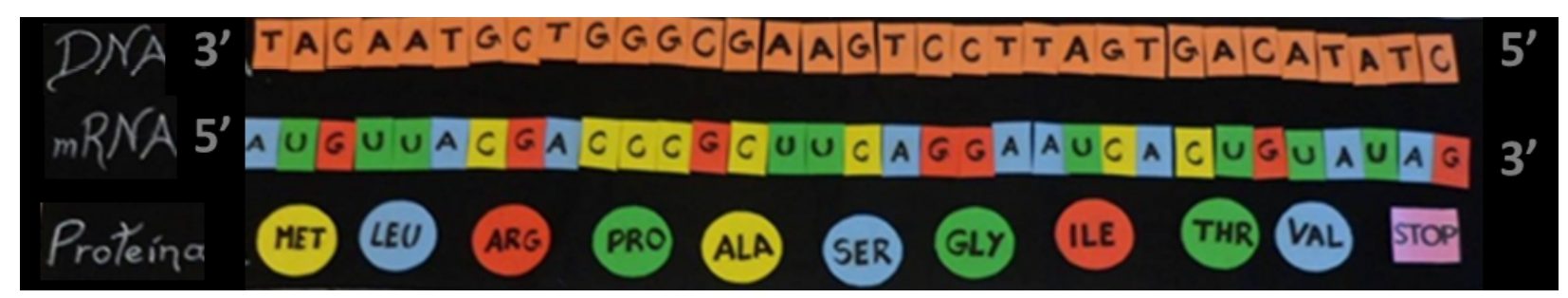

Figura 1. Montagem das sequências. A sequência de DNA fita molde é dada pelo docente (fileira superior). Em seguida a transcrição dessa sequência em mRNA é realizada pelos alunos (fileira do meio). Esta etapa se conclui na tradução da sequência de mRNA em uma sequência de aminoácidos para formar a proteína (fileira inferior).

\subsection{Dinâmica do Jogo}

O número máximo de participantes do jogo é cinco. O número de peças de bases nitrogenadas que compõe a fita de DNA é de 60,15 para cada base $(A, T, C, G) .60$ peças também são necessárias para a fita de mRNA, 15 para cada base nitrogenada $(A, U, C, G)$. 20 círculos menores para compor a sequência de aminoácidos da proteína e mais 20 círculos maiores para montar o jogo Twister no "chão".

O jogo é divido em três etapas: a primeira etapa corresponde ao processo de transcrição e formação do mRNA a partir da fita molde de DNA pré-definida pelo docente 
utilizando as peças laranjas, com base em conhecimentos teóricos pré-abordados em sala de aula (Figura 1); a segunda etapa corresponde ao processo de tradução e formação da sequência linear de aminoácidos obtendo a proteína em sua conformação primária (essa tradução é feita pelas trincas estabelecidas dos 20 aminoácidos, demonstrados na tabela do código genético que deve ser entregue aos participantes no início do jogo (Figura 2); a terceira etapa é o dobramento proteico do qual cada membro do grupo representa dois aminoácidos (com excessão do primeiro que representa apenas Met). O discente simbolizará uma ligação entre os aminoácidos que representa e entre os demais participantes. O mecanismo dos ribossomos e RNA transportador não é representado, mas pode ser relembrado pelo docente durante a prática (Figuras 3 e 4).

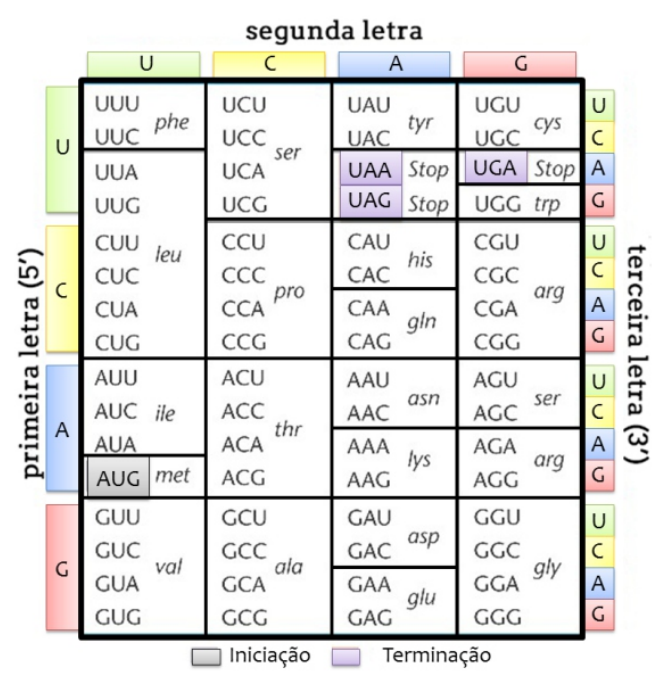

Figura 2. Código Genético. Os alunos recebem o código genético durante o jogo para traduzir o mRNA e encontrar a sequência de aminoácidos. Figura adaptada de Griffiths AJF, et al. 2000. [13]

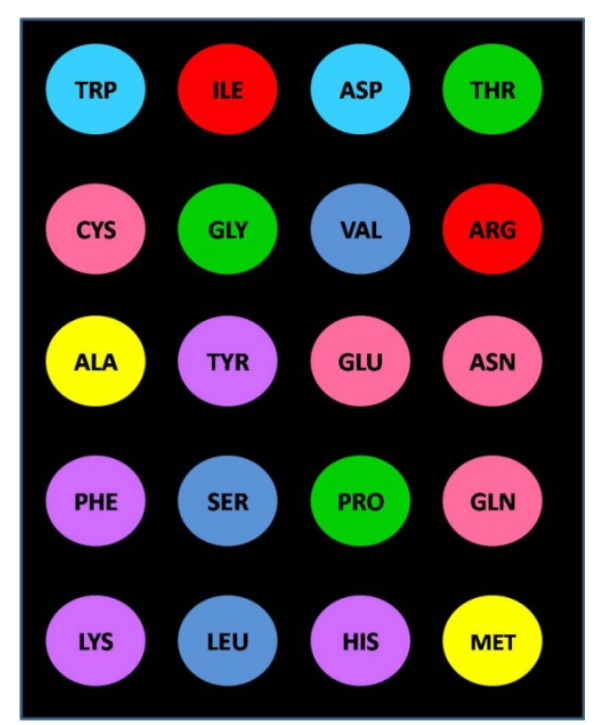

Figura 3. Aminoácidos agrupados para a formação tridimensional das proteínas, como no jogo "Twister". Os discos maiores contendo a abreviação dos aminoácidos são afixados de forma aleatória no tapete (papel pardo) a fim de servir como suporte para o dobramento proteico realizado pelos alunos na etapa final do jogo. 
O grupo de cinco alunos participantes representará a proteína estabelecida pela fita molde na sua conformação in natura (tridimensional) no chão. A união entre os aminoácidos que o participante representa acontece, como na teoria, pela ligação peptídica, seu corpo, (perna esquerda representando grupamento carboxil e mão direita representando grupamento amina) e as demais interações que unem os participantes pela perna direita e mão esquerda.

Por exemplo: o primeiro aluno, seguindo o exemplo do $4^{\circ}$ passo, terá o pé esquerdo no Met e a mão direita no Leu, a mão esquerda segurará o pé direito "livre" do próximo participante (Figura $4 \mathrm{C}$ ), este, terá o pé esquerdo no Arg e a mão direita em Pro e segurará com a mão esquerda o pé direito do próximo que segue com o pé esquerdo em outro aminoácido (Ala) e assim sucessivamente (Figura 4A e B). O pé esquerdo e a mão direita representam a ligação peptídica covalente e geram a estrutura primária, essa ligação é forte, no jogo representada pelos membros que ficam no chão, firmes e melhor estáveis. O pé direito e mão esquerda representam as demais interações fracas que conferem a tridimensionalidade à molécula (forças van der Waals, ligações de hidrogênio, ligações iônicas) e que a deixam na sua forma ativa (Figura 4C).

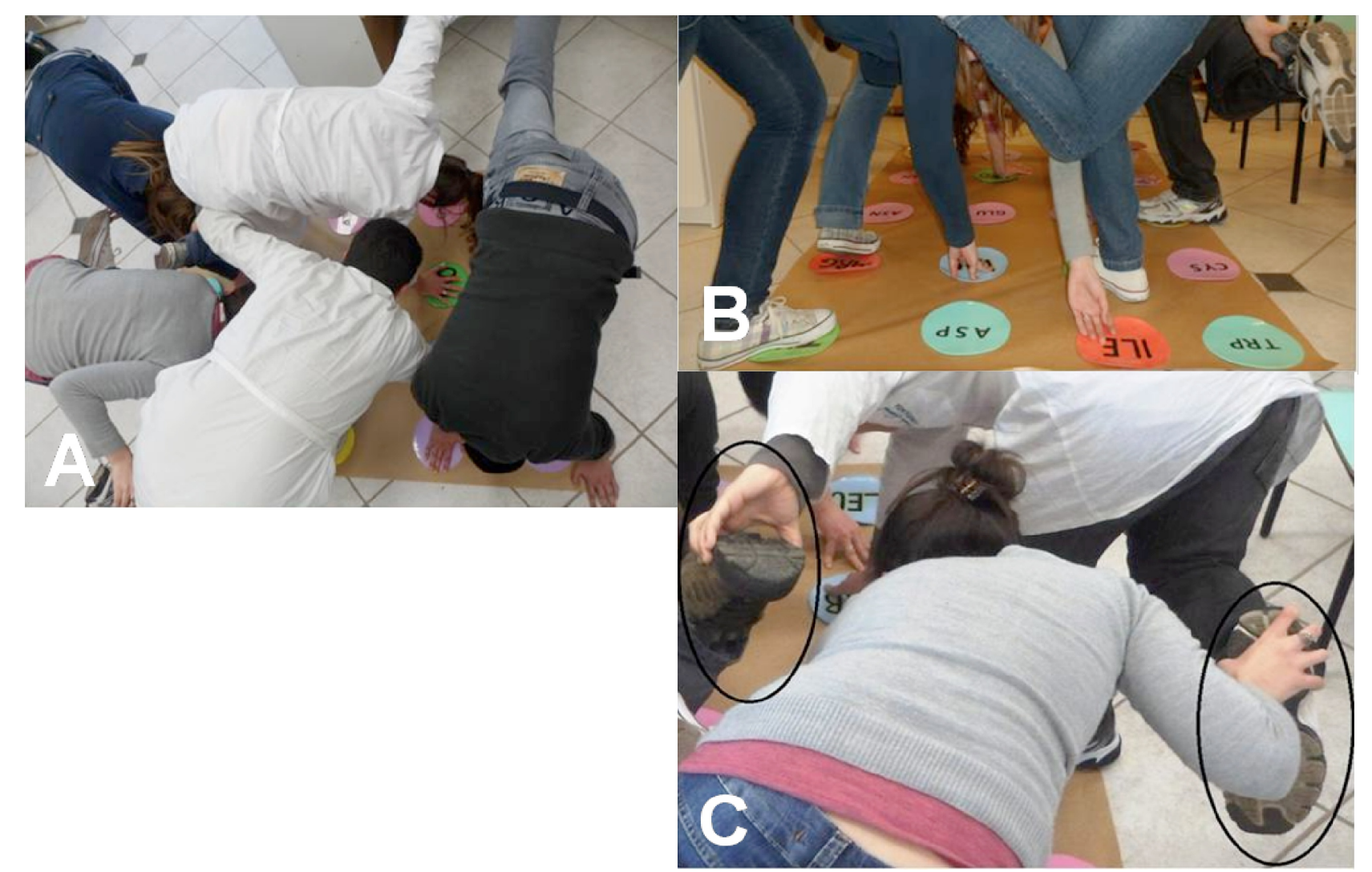

Figura 4. $O$ jogo do Twister, posicionamento dos jogadores. A) Conformação final: forma ativa da proteína; B) Posicionamento de mãos e pés dos jogadores; C) Representação das ligações entre os alunos indicada pelos círculos; $O$ pé esquerdo e a mão direita representam a ligação peptídica covalente e geram a estrutura primária; $O$ pé direito e mão esquerda representam as demais interações que conferem a tridimensionalidade à molécula (forças van der Waals, ligações iônicas e ligações de hidrogênio). 
Estes membros ficam suspensos e são facilmente soltos pelos alunos durante a prática quando o colega está se organizando em seus aminoácidos, demonstrando que tais interações ocorrem, se rearranjam, desfazem e refazem, como auxiliam na estabilidade da proteína. O momento em que os participantes "soltam-se" ou não concluem o enovelamento pode ser considerado como a desnaturação proteica.

\section{Resultados}

Os resultados foram obtidos a partir da aplicação do jogo onde os alunos receberam ao final da aplicação do jogo um questionário adaptado [11] solicitando sua opinião quanto à utilização desta atividade em sala de aula como uma forma alternativa de trazer um melhor aprendizado e memorização do conteúdo teórico abordado (transcrição, tradução e dobramento proteico), bem como, tornar as aulas mais dinâmicas (Apêndice A).

A função educativa do jogo foi facilmente observada durante sua aplicação com alunos da disciplina de citogenética na Universidade Federal do Pampa (UNIPAMPA), verificando-se que favorece a aquisição e sistematização de conhecimentos, em clima de alegria e descontração.

O jogo foi novamente aplicado com alunos da disciplina de Genética, da mesma instituição, os quais responderam ao questionário citado anteriormente (Apêndice A). Das respostas obtidas $100 \%$ dos alunos classificaram a atividade como "boa", sendo possível aprender algum conceito de Genética com a realização da mesma. Quanto à importância do desenvolvimento de práticas para memorização do conteúdo abordado em sala de aula, novamente, $100 \%$ dos alunos considera importante bem como, acreditam que o jogo Twister Proteico permitiu além da melhor memorização uma melhor assimilação dos conceitos teóricos.

A dificuldade do jogo foi avaliada em mais de 50\% como "fácil" pelos alunos (Figura 5) e quando questionados se, no lugar de discentes fossem docentes, aplicariam ou não a atividade, mais de $90 \%$ dos alunos responderam que "sim" (Figura 6). 


\section{Nível de Dificuldade}

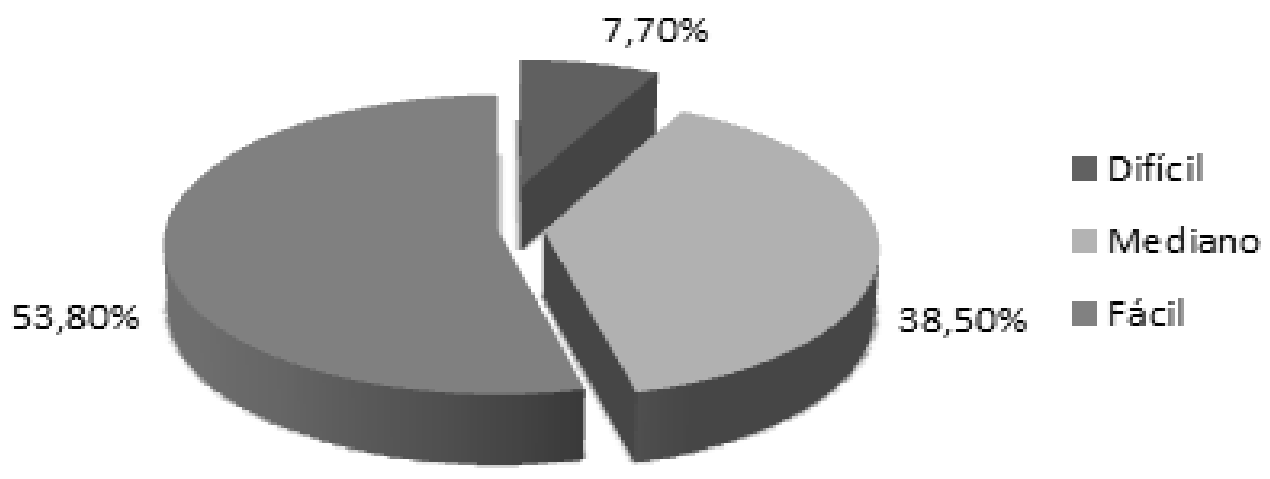

Figura 5. Classificação da dificuldade da atividade proposta segundo opinião dos alunos. Após realização do jogo Twister proteico os alunos opinaram quanto ao nível de dificuldade do mesmo. Nenhum aluno assinalou as opções "muito fácil" ou "muito difícil".

\section{Aplicabilidade da atividade}

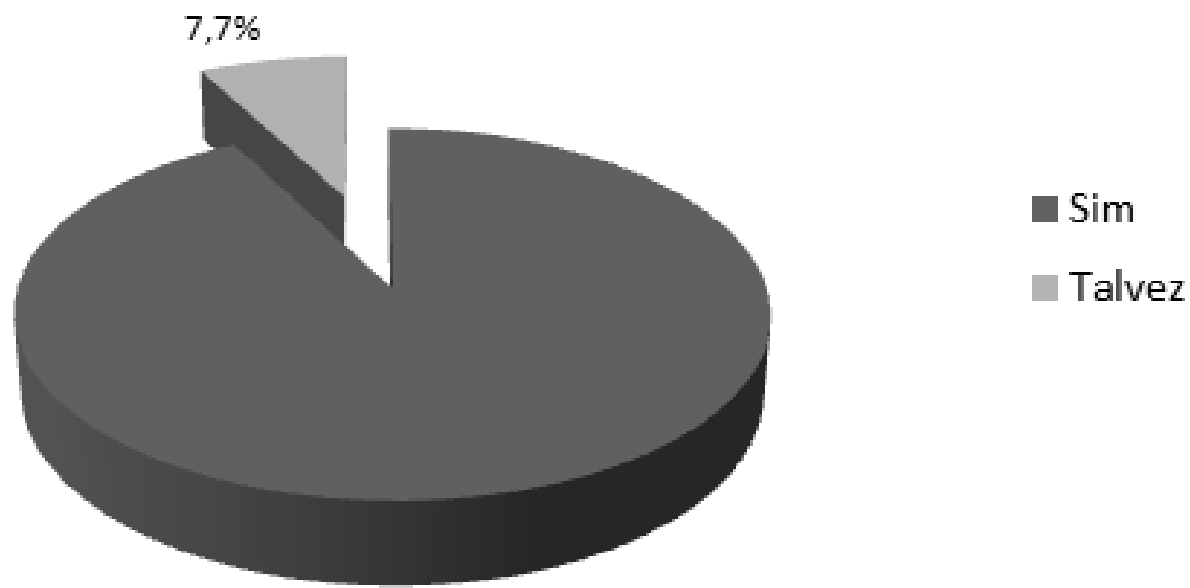

$92,3 \%$

Figura 6. Avaliação dos alunos quando questionados se como professores aplicariam ou não a mesma atividade. Realizada a pergunta: "Se você fosse um professor de ensino médio, aplicaria ou não esta atividade?" os alunos tinham as opções: "Sim", "Não" e "Talvez". Nenhum aluno assinalou a opção "Não", mostrando aceitação e importância da atividade.

A maior dificuldade apontada pelos alunos em aprender Genética foi relacionada como sendo esta de caráter teórico complexo com mais de $50 \%$ dos votos obtidos, seguido pela dificuldade em visualizar os fenômenos a nível celular e molecular, 30,8\% (Figura 7). 


\section{Dificuldade no aprendizado de Genética}

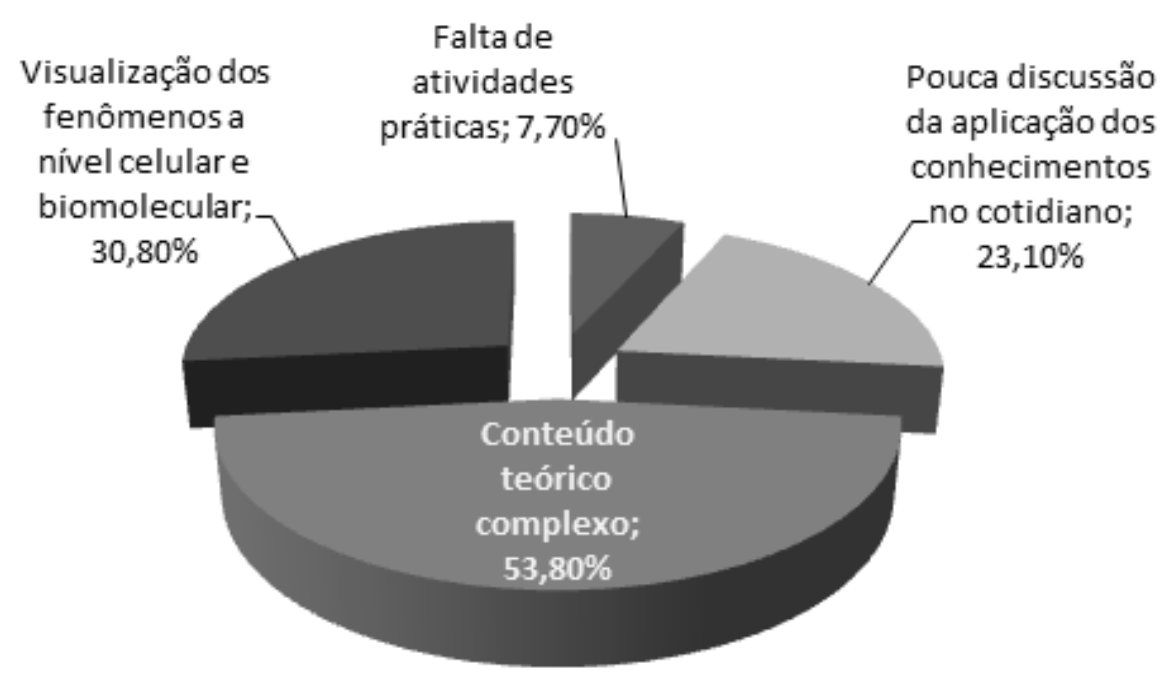

Figura 7. Opinião discente quanto às maiores dificuldades encontradas no processo de aprendizagem de Genética. Dentre as opções fornecidas no questionário para a questão 6: "Na sua opinião, quais são as maiores dificuldades atualmente apresentadas no processo de aprendizado de Genética?", a opção "Conteúdo teórico complexo" destacou-se com mais de 50\% dos votos.

Dentre as dificuldades encontradas durante o desenvolvimento da atividade, a visualização na prática dos conhecimentos teóricos obtidos em aula levou destaque com $30,8 \%$ dos votos obtidos e $23 \%$ dos alunos não encontraram dificuldade alguma no jogo aplicado (Figura 8).

\section{Dificuldade encontrada durante o jogo}

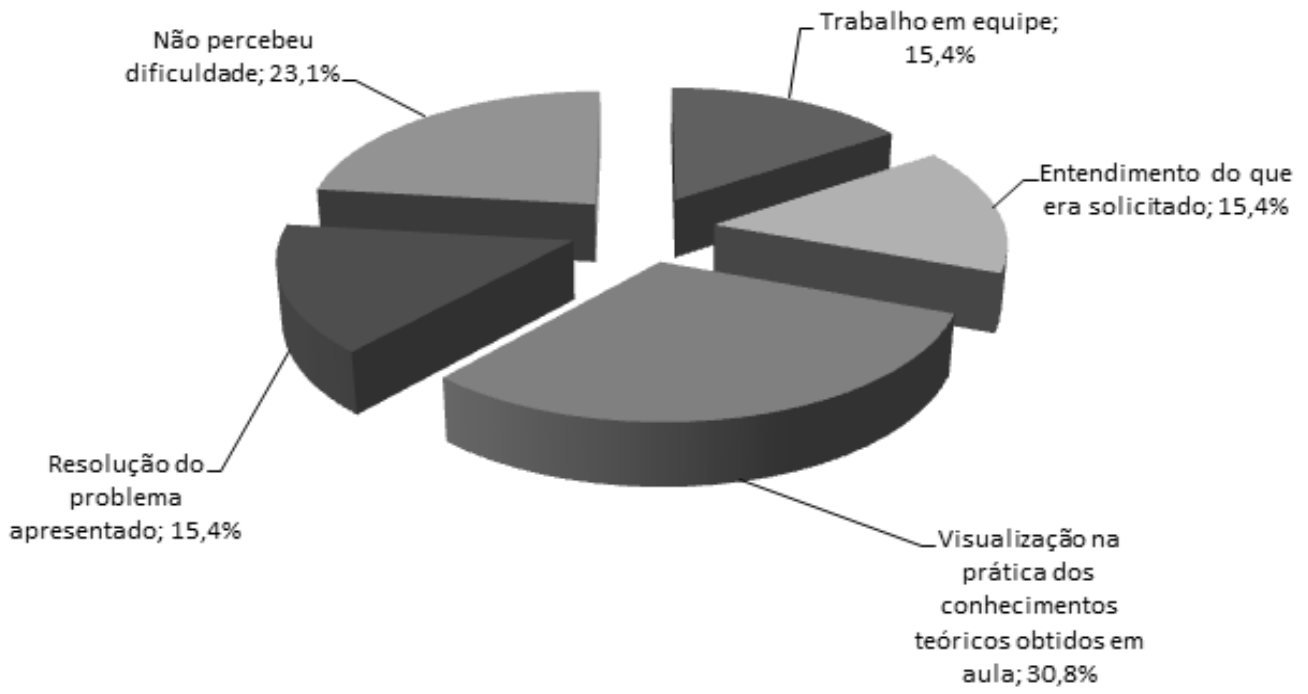

Figura 8. Opinião dos discentes quanto às dificuldades encontradas durante a aplicação do Twister Proteico. A maior problemática encontrada pelos alunos na atividade foi de visualizar na prática os conhecimentos teóricos obtidos em sala de aula. 


\section{Discussão}

A dinâmica inicia com trabalho em equipe logo no início do jogo, motivando interação, discussão e revisão de conceitos básicos de transcrição e tradução abordados em sala de aula para poder iniciar a brincadeira. Como no jogo "Twister ${ }^{\circledR "}$ no momento da conformação tridimensional (enovelamento proteico) onde os aminoácidos (participantes) se unem, há um fortalecimento maior da amizade e confiança entre os participantes. Nesse cenário, concordamos com Campos et al. [7] que os jogos didáticos favorecem a motivação interna, o raciocínio, a argumentação, a interação entre alunos e entre alunoprofessor.

As maiores dificuldades encontradas durante a aplicação do jogo, do ponto de vista do aplicador, foram com os alunos que não lembravam do processo da síntese proteica, pois se investe um tempo extra ensinando todo o processo novamente. Sugere-se aplicar o jogo depois de ministrada a aula teórica ou como uma forma de revisão deste conteúdo. O jogo é indicado aos alunos de graduação das áreas biológicas, pois é necessário um conhecimento prévio de Genética e síntese proteica, contudo, nada impede de ser utilizado em nível de ensino médio se o tema for previamente abordado.

Outra dificuldade observada foi que os grupos de alunos que não compartilhavam amizade ou que não tinham condições físicas e estruturais medianas, ficavam receosos na prática da última etapa do jogo, devido à conformação causada pelas ligações dos aminoácidos. Os autores sugerem que o docente deve ater-se para mediar esta interação entre alunos tornando o jogo mais descontraído e elaborar algumas estruturas da última etapa mais acessíveis para o caso de haverem alunos de condições físicas menos favorecidas, como por exemplo, indicar uma posição de aminoácidos mais aproximada para aquele aluno permitindo, assim, a inclusão do mesmo na dinâmica.

Partindo para a avaliação do jogo realizada pelos discentes através do questionário (Apêndice A), observa-se uma excelente aceitação da atividade por parte dos estudantes onde, estes, comentam a positividade da atividade como um favorecimento da fixação de conteúdos pré-abordados de forma mais prazerosa de aprender, uma melhor memorização e a importância de práticas como a Twister proteico para consolidação da teoria. De modo geral, conteúdos como duplicação do material genético, ácidos nucleicos, aminoácidos, transcrição, tradução, dobramento proteico, pareamento de bases, ligações entre aminoácidos, funcionalidade proteica, e outras dúvidas geradas na teoria foram assimiladas com a prática. Dessa forma é possível dizer que a ludicidade incorporada no ensino de Genética se torna uma ferramenta facilitadora viável na aprendizagem, 
auxiliando na memorização e ligação da teoria com a prática de conteúdos abordados em sala de aula como já mencionava Falkembach ao discutir o lúdico e os jogos educacionais [12]:

\begin{abstract}
"Em um jogo a carga informativa pode ser significativamente maior, os apelos sensoriais podem ser multiplicados e isso faz com que a atenção e o interesse do aluno sejam mantidos, promovendo a retenção da informação e facilitando a aprendizagem".
\end{abstract}

Analisando-se o grau de dificuldade, a maioria dos alunos relata a atividade como de caráter fácil a mediano, talvez pelo esquecimento de conceitos pré-abordados, necessários para realização da prática, os quais conforme eram lembrados tornavam a dinâmica mais fluida e descontraída.

Mais de $90 \%$ dos alunos considerou importante a aplicação de dinâmicas, como a abordada neste trabalho, para o ensino de Genética, tendo como justificativas: uma melhor interação aluno-professor, bem como, entre colegas; descontração do ambiente de sala de aula; melhor visualização da teoria; retenção da atenção no conteúdo proposto e o fato de que atividades diferentes proporcionam maior interesse e servem como fuga da rotina facilitando a revisão e fixação de conteúdos pré-abordados. Essas respostas concordam com o já observado em diversas literaturas onde o jogo se torna uma alternativa mais atraente servindo de apoio à teoria, retendo maior atenção e conferindo diversas vantagens no aprendizado como cita Falkembach em seu texto [12]:

\footnotetext{
"As crianças podem reforçar conteúdos vistos em aula de uma maneira atraente e gratificante. [...] Um jogo bem concebido e utilizado de forma adequada oferece muitas vantagens, entre elas: fixa os conteúdos, ou seja, facilita a aprendizagem; permite a tomada de decisão e avaliações; dá significado a conceitos de difícil compreensão; requer participação ativa; socializa e estimula o trabalho de equipe; motiva, desperta a criatividade, o senso crítico, a participação, a competição sadia e o prazer de aprender."
}

Quando questionados sobre as dificuldades no ensino e aprendizado de Genética, $80 \%$ dos discentes aponta o caráter teórico complexo e a dificuldade em visualizar os fenômenos a nível celular e molecular como principais motivos encontrados. As respostas são retomadas durante o desenvolvimento da atividade, onde, a visualização na prática da teoria obteve maior pontuação como problemática (30,8\%). Este fenômeno vem se repetindo há anos e a busca por alternativas que visem a solução deste problema tem se tornado prioridade na atividade do ensino de Genética. Agamme, [11] relata essa dificuldade e aponta a necessidade de criar um link entre o abstrato e o cotidiano visando despertar um melhor interesse por parte dos alunos facilitando, assim, a aprendizagem dos conteúdos abordados. Como ela mesma cita: 
[...] o ensino de genética vem enfrentando algumas dificuldades, dentre elas estão: despertar o interesse do aluno, fazê-lo entender processos que envolvem conceitos abstratos e descobrir formas de ajudar o aluno a perceber a relação que existe entre os conhecimetos científicos e o cotidiano.

Ferramentas lúdicas de apoio ao ensino de Genética, possibilitam criar esta ligação entre teoria e prática de forma simples e eficiente, sendo sugerido por este trabalho a real importância que apresentam na visualização de forma dinâmica e descontraída. É sugerido que práticas como a deste trabalho recebam maior importância e passem a servir como exemplo para a solução desta problemática que ainda vem sendo apresentada.

\section{Impacto no ensino-aprendizado}

Ferramentas lúdicas são essenciais no desenvolvimento de habilidades sensoriais, ajudando a memorizar fatos e conceitos, retendo a atenção dos alunos, motivando, estimulando curiosidade, criatividade, socialização e melhorando seu rendimento. Esse jogo permite a visualização na prática do conteúdo teórico de Genética que aborda transcrição, tradução e dobramento proteico.

A atividade proposta é de fácil confecção, realização e visualização, além de utilizar materiais de fácil acesso e baixo custo. Dessa forma, pode ser aplicada em aulas práticas de Genética e Bioquímica, e também em outros cursos de graduação ou ensino médio, onde o conteúdo teórico tenha sido previamente abordado.

\section{Conclusão}

O ensino de Genética pode ser facilitado, por meio da construção de modelos de jogos didáticos devidamente trabalhados com os alunos, pois, além de despertar seus interesses pelo tema, também permite que o docente reconheça as dificuldades de aprendizado dos alunos e a forma como as informações estão sendo compreendidas e assimiladas.

O presente trabalho demonstrou ter alcançado os objetivos propostos inicialmente com êxito e durante sua aplicação obteve grandes melhorias acrescentadas pelos discentes participantes. Os alunos comentaram a melhor memorização e absorção dos conhecimentos teóricos de Genética e associam este fato a dinamicidade e fuga da rotina. 
Pelo exposto, entendemos que o jogo é digno de um espaço e tempo maior na prática pedagógica cotidiana dos professores, servindo como ferramenta auxiliar de baixo custo e grande aplicabilidade no ensino de Genética.

\section{Referências Bibliográficas}

[1] Klautau N, Aurora A, Dulce D, Silviene S, Helena H, Correia A. Relação entre herança genética, reprodução e meiose: um estudo das concepções de estudantes universitários do Brasil e Portugal. In Enseñanza de las Ciencias, Número Extra VIII Congreso Internacional sobre Investigación en Didáctica de lãs Ciencias.; 07 a 11 de setembro de 2009., Barcelona, Espanha. p. 2267-2270. Disponível em:http://ensciencias.uab.es/congreso09/numeroextra/art-2267-2270.pdf , Acesso em: 28 de julho de 2012.

[2] Jann PN, Leite MF. Jogo do DNA: um instrumento pedagógico para o ensino de ciências e biologia. Ciências e Cognição. 2010; v.15 (1): 282-293.

[3] Krasilchik M. Prática de Ensino de Biologia. 4. ed. São Paulo: Editora da Universidade de São Paulo; 2004, p.197.

[4] Kishimoto TM. Jogo, brinquedo, brincadeira e a educação. 1. ed. São Paulo: Cortez; 1996.

[5] Brasil. Secretaria de Educação Fundamental. Parâmetros curriculares nacionais: Educação Física / Secretaria de Educação Fundamental. Brasília: MEC / SEF, 1998. p. 114.

[6] Macedo L, Petty ALS, Passos NC. Os jogos e o Lúdico na Aprendizagem Escolar. 1. ed. Porto Alegre: Artmed; 2005.

[7] Campos LML, Bortoloto TM, Felício AKC. A Produção de jogos didáticos para o ensino de ciências e biologia: uma proposta para favorecer a aprendizagem. Caderno dos Núcleos de Ensino. São Paulo. 2003. Acesso em: 20 de maio de 2012. Disponível em: http://www.unesp.br/prograd/PDFNE2002/aproducaodejogos.pdf.

[8] Rieder R, Zanelato EM, Brancher JD. Observação e análise da aplicação de jogos educacionais bidimensionais em um ambiente aberto. In IX Taller Internacional de Software Educativo.; 01, 02 e 03 de dezembro de 2004., Santiago, Chile. TISE. 2004. 6166. 
[9] Zanon DAV, Guerreiro MAS, Oliveira RC. Jogo didático Ludo Químico para o ensino de nomenclatura dos compostos orgânicos: projeto, produção, aplicação e avaliação. Revista Ciências e Cognição 2008; v.13 (1): 72-81.

[10] Miranda S. No Fascínio do jogo, a alegria de aprender. Ciência Hoje 2001; v.28 (168): 64-66.

[11] Agamme ALDA. O lúdico no ensino de genética: a utilização de um jogo para entender a meiose. Monografia, Universidade Presbiterana Mackenzie. Centro de Ciências Biológicas e da Saúde. São Paulo. 2010.

[12] Falkembach GAM. O Lúdico e os Jogos Educacionais. Mídias na Educação. CINTED - Centro Interdisciplinar de Novas Tecnologias na Educação. UFRGS. 2006. Acesso em 16 de novembro de 2014 Disponível em:

http://penta3.ufrgs.br/midiasedu/modulo13/etapa1/leituras/arquivos/Leitura_1.pdf.

[13] Griffiths AJF, Miller JH, Suzuki DT, Lewontin RC, Gelbart WM. An Introduction to Genetic Analysis. 7. ed. Nova lorque: W. H. Freeman; 2000.

\section{Agradecimentos}

A Tiago Degrandi, Thiago de Freitas, Carlos Almeida, Ana Paula Perin, Graziela Stürmer, Ana Paula Lucho e às turmas das disciplinas de Citogenética e Genética Básica da Unipampa São Gabriel pela colaboração no trabalho. A Prof ${ }^{a}$ Berenice Soares Bueno pelas valiosas sugestões. 


\section{APÊNDICE A. Questionário}

\section{Twister Proteico}

O questionário a seguir possui a finalidade de avaliar a atividade proposta, Twister Proteico. Assinale com $\mathrm{X}$ a alternativa que julgar mais adequada e justifique quando for solicitado. Procure responder com a maior sinceridade possível. O tempo para responder ao questionário será de 10 minutos. Ao terminar, entregue ao pesquisador ou professor(a).

\section{Agradecemos pela sua colaboração com esta pesquisa!}

1. A respeito da atividade desenvolvida, classifique-a:
( ) Boa
( ) Regular
( ) Ruim
Observações:

2. Para você, qual foi o nível de dificuldade da atividade?
( ) Muito difícil
( ) Difícil
( ) Mediano
( ) Fácil
( ) Muito fácil

3. Quais foram as principais dificuldades apresentadas durante o desenvolvimento da atividade?

( ) Trabalho em equipe

( ) Entendimento do que se era solicitado

( ) Material utilizado

( ) Visualização na prática dos conhecimentos teóricos obtidos em aula

( ) Resolução do problema apresentado

( ) Outros. Qual (is)?

4. Se você fosse um professor do ensino médio/superior, aplicaria esta atividade?
( ) $\operatorname{Sim}$
( ) Não
( ) Talvez
Justifique sua resposta:

5-Foi possível aprender algum conceito de Genética com a realização dessa atividade?
( ) Sim - Quais:
( ) Não - Justifique:

6 - $\mathrm{Na}$ sua opinião, quais são as maiores dificuldades atualmente apresentadas no processo de aprendizado da Genética?

( ) Falta de atividades práticas

( ) Pouca discussão da aplicação dos conhecimentos no cotidiano

( ) Conteúdo teórico complexo

( ) Visualização dos fenômenos a nível celular e molecular

( ) Pouco acesso a softwares e modelos experimentais

( ) Outros:

7 - Você considera importante práticas como a desenvolvida, Twister Proteico, para memorização do conteúdo abordado em sala de aula?
( ) Sim
( ) Não

8 - Você acredita que:

( ) O Jogo é confuso e atrapalha a absorção do conteúdo teórico

( ) O Jogo permitiu melhor memorização e assimilação do conteúdo teórico

( ) O Jogo foi indiferente

Sugestões, elogios e críticas: 